\title{
EVALUASI KURIKULUM SEKOLAH MENENGAH JURUSAN AKUNTANSI MENJELANG IFRS
}

\author{
Holly Deviarti; Heny Kurniawati \\ Jurusan Akuntansi, Fakultas Ekonomi dan Komunikasi, BINUS University \\ Jln. K.H. Syahdan No. 9, Kemanggisan, Palmerah, Jakarta Barat 11480 \\ Bunda_mustafa@binus.edu' ${ }^{1}$; hkurniawati@binus.edu ${ }^{2}$
}

\begin{abstract}
The changing of financial accounting standard into International Financial Report Standard (IFRS) is the headline for all accountants, for professional public, company and academic accountants. The purpose of this research is to evaluate the curriculum of vocational high school (SMK) accounting major in the advance of applying IFRS. The method used is descriptive explorative approach. This research started through library research, interview with teachers, hold trainings and questionnaire, and analyze the activities. The result showed that SMK in accounting major is not ready yet for the advance of IFRS convergence in 2012, so does the knowledge socialization among teachers and instructors. The researcher recommended holding the preparation for PSAK in IFRS convergence curriculum-based (in cooperation with fostering directorate of vocational high school), training for teachers, arranging accounting books or modules, and adding subjects about IFRS for opening knowledge.
\end{abstract}

Keywords: IFRS, accounting, vocational high school, curriculum

\begin{abstract}
ABSTRAK
Perubahan standar akuntansi keuangan menuju International Financial Report Standard (IFRS) adalah berita utama untuk setiap akuntan, baik profesi akuntan publik, akuntan perusahaan maupun akuntan akademis. Tujuan umum penelitian ini adalah mengevaluasi kurikulum Sekolah Menengah Kejuruan (SMK) Jurusan Akuntansi menjelang diterapkannya IFRS. Metode penelitian ini akan memakai pendekatan deskriptif exploratif. Penelitian ini diawali dengan melakukan studi pustaka, melakukan wawancara dengan para guru, menyelenggarakan pelatihan, mengadakan kustioner, dan terakhir melaksanakan analisa hasil kegiatankegiatan tersebut. Hasil penelitian menunjukkan masih belum siapnya kurikulum SMK jurusan Akuntansi menjelang konvergensi IFRS pada 2012, begitu halnya akan sosialisasi keilmuan para guru atau tenaga pengajar. Saran yang diberikan adalah persiapan kurikulum berbasis PSAK konvergensi IFRS (dengan bekerjasama bersama Direktorat Pembinaan Sekolah Menengah Kejuruan), pelatihan guru, penyusunan buku atau modul akuntansi, dan penambahan mata pelajaran tentang IFRS sebagai pembuka wawasan.
\end{abstract}

Kata kunci: IFRS, SMK, akuntansi, kurikulum 


\section{PENDAHULUAN}

Perubahan peraturan Standar Akuntansi Keuangan (SAK) dikarenakan kehadiran International Financial Reporting Standard (IFRS) bagi perguruan tinggi jurusan akuntansi dalam kurun waktu 3 tahun terakhir adalah suatu hal yang tidak asing lagi, karena maraknya pelatihan untuk para dosen maupun mahasiswa dalam rangka memperbaiki kurikulum yang sudah ada. Berbeda halnya dengan Sekolah Menengah Jurusan (SMK) yang lebih disibukkan dengan aktivitas pembelajaran yang sifatnya sangat klerikal dan rutinitas. Informasi perubahan PSAK tidak secara merata tersebar keseluruh guru akuntansi. Guru-guru akuntansi hanya memberikan pengajaran berdasarkan buku lokal dan kurikulum yang sudah ditetapkan oleh Direktorat Pembinaan Sekolah Menengah Kejuruan. Peraturan metode dan model pengajaran yang kaku serta tidak mengikuti perkembangan kebutuhan standar akuntansi mengakibatkan tertinggalnya keilmuan untuk para guru dan murid SMK. Berdasarkan uraian alasan tersebut maka kami tertarik melaksanakan penelitian yaitu Evaluasi Kurikulum Sekolah Menengah Jurusan Akuntansi Menjelang IFRS.

Rumusan masalah dalam penelitian ini adalah bagaimanakah kurikulum sekolah menengah jurusan akuntansi menjelang penerapan IFRS dan bagaimanakah kesiapan para tenaga pengajar atas PSAK konverjensi IFRS. Dua tujuan utama yang ingin dicapai oleh penelitian adalah mendapatkan hasil analisa kurikulum sekolah menengah jurusan akuntansi dan mendapatkan hasil analisa kesiapan para tenaga pengajar atas PSAK konverjensi IFRS. Pentingnya penelitian yang ingin dicapai yaitu menilai kurikulum SMK jurusan akuntansi yang sedang berjalan, mendapatkan data dan informasi atas kesiapan keilmuan tenaga pengajar akan PSAK konverjensi IFRS dan SAK ETAP berdasarkan kebutuhan untuk pendidikan, dan pembelajaran bagi pihak-pihak yang terkait. Apalagi dengan didengang-dengungkannya suatu kurikulum pendidikan yang link-and-match dengan kebutuhan tenaga kerja.

Kurikulum adalah suatu rencana yang disusun untuk melancarkan proses berlajar mengajar di bawah bimbingan dan tanggung jawab sekolah atau lembaga pendidikan beserta staf pengajarnya (Nasution, 2008). Pada dasarnya kurikulum memiliki tiga dimensi pengertian, yakni: (1) kurikulum sebagai mata pelajaran; (2) kurikulum sebagai pengalaman belajar; dan (3) kurikulum sebagai perencanaan program pembelajaran.

\section{Pengertian Kurikulum}

Kurikulum sebagai mata pelajaran memiliki pengertian, bahwa sejumlah mata pelajaran yang harus ditempuh peserta didik. Dalam konsep ini kurikulum erat kaitannya dengan usaha memperoleh ijazah. Maksudnya apabila siswa telah berhasil mendapatkan ijazah berarti ia telah mampu menguasai pelajaran sesuai kurikulum yang berlaku.dengan demikian, pandangan kurikulum berorientasi pada isi atau materi pelajaran. Konsep ini merupakan sebuah konsep yang tradisional, meskipun saat ini masih banyak dianut dalam dunia pendidikan.

Kurikulum sebagai pengalaman belajar, berawal dari tuntutan baru mayarakat terhadap sekolah agar lulusan sebuah lembaga pendidikan/sekolah tidak hanya membekali peserta didik dengan ilmu pengetahuan, akan tetapi juga dituntut untuk dapat mengembangkan minat dan bakat, membentuk moral dan kepribadian, bahkan dituntut agar anak dapat menguasai berbagai macam ketrampilan untuk memenuhi kebutuhan dunia pekerjaan. Istilah kurikulum sebagai pengalaman belajar yang dapat diartikan dalam eksra kurikuler ataupun intra kurikuler, bahkan tak terbatas hanya itu apapun yang dilakukan siswa asalkan masih dalam pengawasan guru termasuk di dalam kurikulum. Konsep ini didukung pendapat beberapa ahli: "... all of experiences children have under the guidance of teacher" (Caswell \& Campbell, 1935). 
Demikian juga menurut Lee \& Lee (1940) yang menyatakan kurikulum sebagai: “...those experiences of the child which the school in any way utilizes or attempts to influence". Pergeseran makna kurikulum dari pata pelajaran menjadi pengalaman belajar juga dipengaruhi penemuan dalam bidang psikologi belajar, yakni pandangan tentang belajar tidak hanya mengumpulkan pengetahuan, akan tetapi merupakan proses perubahan perilaku siswa. Hal ini bisa terjadi bila siswa memiliki pengalaman belajar.

Kurikulum sebagai program atau rencana pembelajaran, sebuah konsep yang didukung oleh beberapa ahli pendidikan diantaranya; Print (1993) yang menyatakan: "Curriculum is defined as all the planned learning opportunities offered to learner by the educational institution and the experiences learners encounter when the curriculum is implemented". Hilda Taba (1962) menyatakan: "A curriculum is a plan for learning; therefore, what is known about the learning process and the development of the individual has bearing on the shaping of a curriculum". Konsep kurikulum sebagai program atau rencana pembelajaran sejalan dengan rumusan kurikulum menurut UndangUndang Nomor 20 Tahun 2003 tentang sistem Pendidikan Nasional, yakni: "Seperangkat rencana dan pengaturan mengenai isi dan bahan pelajaran serta cara yang digunakan sebagai pedoman penyelenggaraan kegiatan pembelajaran untuk mencapai tujuan pendidikan.” Batasan kurikulum menurut Undang-Undang Nomor 20 tahun 2003 memiliki dua aspek pengertian, yakni: Pertama, sebagai rencana (as plan) yang harus dijadikan pedoman dalam pelaksanaan proses pembelajaran oleh guru. Kedua, pengaturan isi dan cara pelaksanaan rencana pembelajaran (Shvoong.com, 2012).

\section{Pengertian Kompetensi Sosial dan Profesional Guru}

Menurut Undang-undang No.14 tahun 2005 tentang Guru Dan Dosen Pasal 10 ayat (1), kompetensi guru meliputi kompetensi pedagogik, kompetensi kepribadian, kompetensi sosial, dan kompetensi profesional yang diperoleh melalui pendidikan profesi.

Kompetensi profesional adalah penguasaan materi pembelajaran secara luas dan mendalam, yang mencakup penguasaan materi kurikulum mata pelajaran di sekolah dan substansi keilmuan yang menaungi materinya, serta penguasaan terhadap struktur dan metodologi keilmuannya. Kompetensi profesional merupakan penguasaan materi pembelajaran secara luas dan mendalam, yang mencakup penguasaan materi kurikulum mata pelajaran di sekolah dan substansi keilmuan yang menaungi materinya, serta penguasaan terhadap struktur dan metodologi keilmuannya.

Menguasai substansi keilmuan yang terkait dengan bidang studi memiliki indikator esensial: memahami materi ajar yang ada dalam kurikulum sekolah; memahami struktur, konsep dan metode keilmuan yang menaungi atau koheren dengan materi ajar; memahami hubungan konsep antar mata pelajaran terkait; dan menerapkan konsep-konsep keilmuan dalam kehidupan sehari-hari. Menguasai struktur dan metode keilmuan memiliki indikator esensial menguasai langkah-langkah penelitian dan kajian kritis untuk memperdalam pengetahuan atau materi bidang studi. Banyak ahli pendidikan yang memberikan koreksi seharusnya lebih cocok digunakan istilah kompetensi akademik.

Sub kompetensi dalam kompetensi profesional adalah: (1) menguasai substansi keilmuan yang terkait dengan bidang studi yang meliputi memahami materi ajar yang ada dalam kurikulum sekolah, memahami struktur, konsep dan metode keilmuan yang menaungi atau koheren dengan materi, memahami hubungan konsep antar mata pelajaran terkait, dan menerapkan konsep-konsep keilmuan dalam kehidupan sehari-hari; dan (2) menguasai struktur dan metode keilmuan yang meliputi menguasai langkah-langkah penelitian dan kajian kritis untuk memperdalam pengetahuan dan materi bidang studi. Kegiatan yang termasuk kompetensi guru khususnya dalam lingkup pengelolaan belajar mengajar adalah memilih dan dapat menggunakan metode mengajar. Mengenali fungsi sekolah sebagai lembaga sosial yang secara potensial dapat memajukan masyarakat dalam arti luas serta pengaruh timbal balik antar sekolah dan masyarakat merupakan kemampuan yang mesti dimiliki guru. 
Hal ini terutama berkaitan dengan kompetensi professional dalam bidang penguasaan landasanlandasan pendidikan.

Kemampuan mengelola interaksi belajar mengajar meliputi kegiatan mengkaji faktor-faktor positif dan negatif dalam proses belajar. Mekanisme psikologis belajar mengajar di sekolah mencakup transfer reinforcement dan retention. Selain itu tugas guru bukan hanya sebagai transfer of knowledge tetapi juga transfer of value. Pribadi dan tingkah laku guru juga dijadikan sebagai tauladan bagai para siswanya, sehingga landasan pendidikan harus tercermin didalam semua perbuatan guru dalam melaksanakan tugas maupun keseharian yang memungkin-kan guru mampu tumbuh dan berkembang dalam jabatan profesionalnya.

Kompetensi sosial adalah kemampuan guru untuk berkomunikasi dan bergaul secara efektif dengan peserta didik, tenaga kependidikan, orang tua/wali peserta didik, dan masyarakat sekitar. Menurut Aritoteles, manusia sebagai mahluk social adalah mahluk yang senantiasa ingin hidup berkelompok. Manusia perlu berinteraksi dengan yang lain senantiasa menjaga hubungan agar tetap berlangsung dalam suasana yang kondusif. Interaksi yang dilakukan guru bertujuan agar peserta didik dan masyarakatnya mampu bertahan hidup (survive) dan berkembang (growth). Misi yang diemban guru dalam masyarakat adalah misi kemanusiaan mengajar dan mendidik. Dalam menunjang kompetensi social guru perlu dilengkapi dengan kemampuan berkomunikasi. Komunikasi yang sebaiknya dilakukan guru adalah komunikasi multi arah dengan orang tua, peserta didik dan masyarakat. Dalam mendukung peningkatan mutu pendidikan, masyarakat membentuk komite sekolah. Dalam hal ini guru dapat melakukan kerjasama dalam hal memberikan laporan mengenai kondisi fasilitas penunjang PBM. Dalam interaksi sesama guru di sekolah para guru dituntut untuk bisa menjadi teman dialog bidang akademik ataupun social yang dihadapi berkenaan dengan peserta didik. Masyarakat yang ada di sekitar sekolah selalu mempengaruhi perkembangan pendidikan di sekolah, karena itu guru wajib mengenal dan menghayati dunia di sekitar sekolah. Dengan kata lain kompetensi sosial guru adalah kemampuan guru dalam mempersiapkan peserta didik menjadi anggota masyarakat yang baik serta kemampuan untuk mendidik, membimbing masyarakat dalam menghadapi kehidupan di masa yang akan datang.

Konverjensi IFRS adalah salah satu kesepakatan pemerintah Indonesia sebagai anggota G20 forum. G-20 merupakan forum diskusi terbuka dan konstruktif antara negara industri dengan Emerging Development Countries (EMDCs) dalam upaya menciptakan stabilitas ekonomi global. Disamping itu G-20 juga melakukan penguatan arsitektur keuangan internasional guna mensupport pertumbuhan global dan melakukan pembentukan agenda internasional pada area-area yang belum dicapainya suatu konsensus serta juga melakukan upaya-upaya pencegahan dan penanggulangan krisis.

Dewan Standar Akuntansi Keuangan (DSAK) Ikatan Akuntan Indonesia (IAI) sedang melakukan konverjensi IFRS dengan target tahun penyelesaian 2012. Sepanjang tahun 2009, DSAKIAI telah mengesahkan 10 PSAK baru, 5 ISAK, mencabut 9 PSAK berbasis industri dan mencabut 1 ISAK.

Dari data-data di atas kebutuhan Indonesia untuk turut serta melakukan program konverjensi tampaknya sudah menjadi keharusan jika kita tidak ingin tertinggal. Sehingga, dalam perkembangan penyusunan standar akuntansi di Indonesia oleh DSAK tidak dapat terlepas dari perkembangan penyusunan standar akuntansi internasional yang dilakukan oleh International Accounting Standards Board (IASB). Standar akuntansi keuangan nasional saat ini sedang dalam proses secara bertahap menuju konverjensi secara penuh dengan IFRS yang dikeluarkan oleh IASB.

Adapun posisi IFRS/IAS yang sudah diadopsi hingga saat ini dan sudah diadopsi pada tahun 2008 dan 2010 adalah seperti yang tercantum berikut ini: 
IFRS/IAS yang Telah Diadopsi ke dalam PSAK hingga 31 Desember 2008

1. IAS 2 Inventories

2. IAS 10 Events after balance sheet date

3. IAS 11 Construction contracts

4. IAS 16 Property, plant and equipment

5. IAS 17 Leases

6. IAS 18 Revenues

7. IAS 19 Employee benefits

8. IAS 23 Borrowing costs

9. IAS 32 Financial instruments: presentation

10. IAS 39 Financial instruments: recognition and measurement

11. IAS 40 Investment property

IFRS/IAS yang telah diadopsi ke dalam PSAK per 23 Desember Tahun 2009

1. IFRS 2 Share-based payment

2. IFRS 4 Insurance contracts

3. IFRS 5 Non-current assets held for sale and discontinued operations

4. IFRS 6 Exploration for and evaluation of mineral resources

5. IFRS 7 Financial instruments: disclosures

6. IAS 1 Presentation of financial statements

7. IAS 27 Consolidated and separate financial statements

8. IAS 28 Investments in associates

9. IFRS 3 Business combination

10. IFRS 8 Segment reporting

11. IAS 8 Accounting policies, changes in accounting estimates and errors

12. IAS 12 Income taxes

13. IAS 21 The effects of changes in foreign exchange rates

14. IAS 26 Accounting and reporting by retirement benefit plans

15. IAS 31 Interests in joint ventures

16. IAS 36 Impairment of assets

17. IAS 37 Provisions, contingent liabilities and contingent assets

18. IAS 38 Intangible assets

$\underline{\text { IFRS/IAS yang Diadopsi ke dalam PSAK pada Tahun } 2010}$

1. IAS 7 Cash flow statements

2. IAS 20 Accounting for government grants and disclosure of government assistance

3. IAS 24 Related party disclosures

4. IAS 29 Financial reporting in hyperinflationary economies

5. IAS 33 Earning per share

6. IAS 34 Interim financial reporting

7. IAS 41 Agriculture

Dan untuk hal-hal yang tidak diatur standar akuntansi internasional, DSAK akan terus mengembangkan standar akuntansi keuangan untuk memenuhi kebutuhan nyata di Indonesia, misalnya standar akuntansi keuangan untuk transaksi syariah, yang diiringi dengan semakin berkembangnya usaha berbasis syariah di tanah air. Landasan konseptual untuk akuntansi transaksi syariah telah disusun oleh DSAK dalam bentuk Kerangka Dasar Penyusunan dan Penyajian Laporan Keuangan Syariah. Hal ini diperlukan karena transaksi syariah mempunyai karakteristik yang berbeda dengan transaksi usaha umumnya sehingga ada beberapa prinsip akuntansi umum yang tidak dapat diterapkan dan diperlukan suatu penambahan prinsip akuntansi yang dapat dijadikan landasan konseptual bagi standar akuntansi keuangan berbasis syariah. Pernyataan Standar Akuntansi Keuangan untuk transaksi syariah akan dimulai dari nomor 101 sampai dengan 200. 


\section{Standar Akuntansi di Indonesia}

Standar aktuntansi di Indonesia disusun oleh Dewan Standar Akuntansi Keuangan. Standar Akuntansi yang disusun adalah PSAK, PSAK ETAP, dan PSAK Syariah. Dewan Standar Akuntansi Keuangan berada dibawah Ikatan Akuntan Indonesia bukan dibawah IAPI (Institut Akuntan Publik Indonesia). Pengurus Pusat IAI, sebagai Dewan Pengawas yang bertugas memilih anggota DSAK, DKSAK, Mekanisme Kerja Dewan Konsultatif Standar Akuntansi Keuangan bertugas memberikan masukan dan arahan kepada DSKA. Untuk Akuntansi Pemerintah disusun oleh Komite Standar Akuntansi Pemerintah.

\section{Pemutakhiran SAK}

Menurut DSAK, pemutakhiran SAK didasarkan pada tiga hal, yaitu: (1) mendukung harmonisasi dan konverjensi PSAK dengan IFRS; (2) dalam perumusan SAK, selain menggunakan referensi IFRS, juga mempertimbangkan berbagai faktor lingkungan usaha di Indonesia; dan (3) pengembangan SAK yang belum diatur dalam IFRS dilakukan berpedoman pada KDPPLK.

PSAK terdiri atas 62 Standards (PSAK), 8 Interpretations (ISAK), 3 Technical Bulletins (add 1 Tech Bulletin has launched April 2009), dan penghapusan beberapa standar industri. Sementara itu, IFRS terdiri atas: 37 Standards, 8 IFRS, 29 IAS, 27 Interpretations, 16 IFRIC Interpretations; dan 11 SIC Interpretations.

\section{METODE}

Metode yang digunakan dalam penelitian ini adalah metode deskriptif exploratif dengan menggunakan data primer maupun sekunder. Tehnik pengumpulan data dilakukan dengan studi lapangan maupun studi kepustakaan.

\section{Alur penelitian}

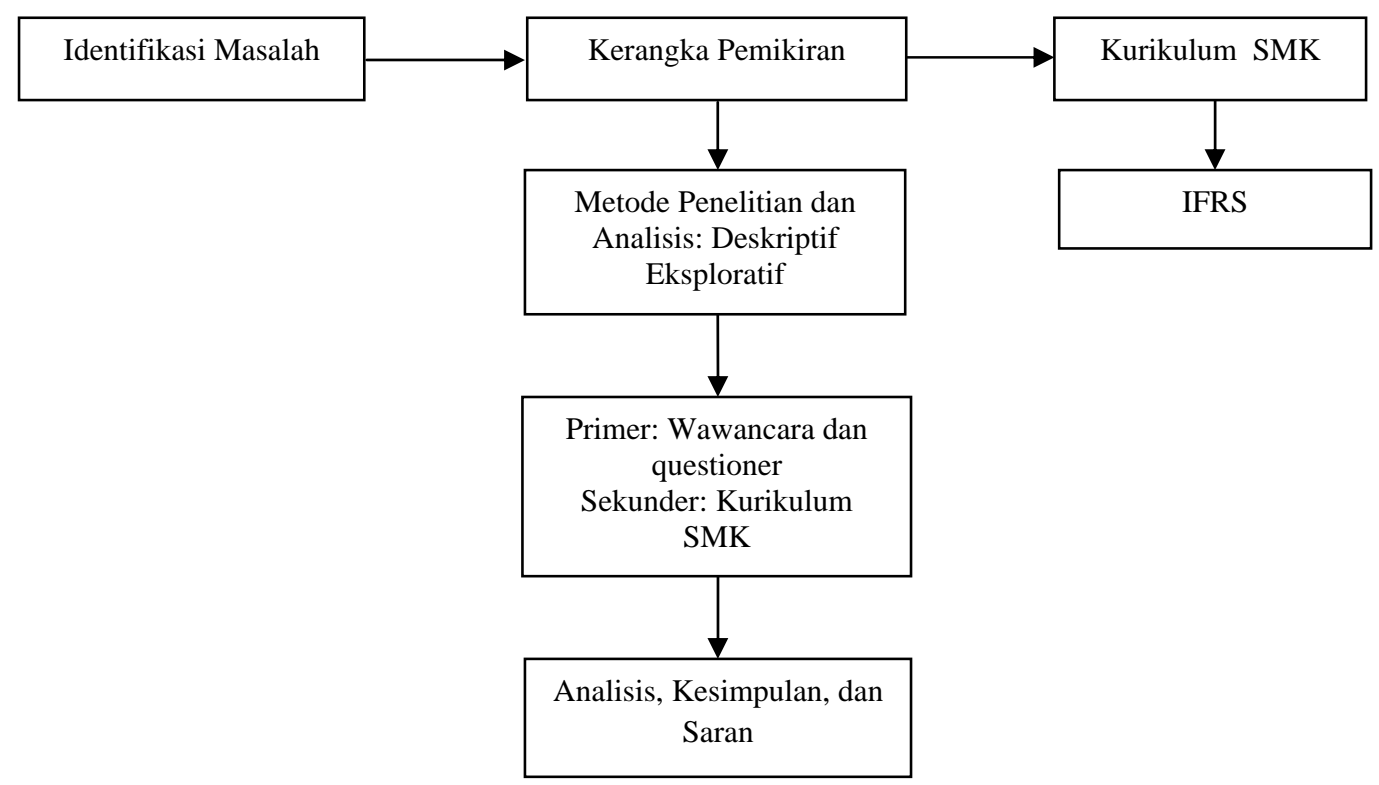




\section{HASIL DAN PEMBAHASAN}

Penelitian ini diawali dengan wawancara di 4 SMK swasta dan SMK negeri. Hasil dari wawancara dengan 4 SMK tersebut, diperoleh informasi bahwa 4 guru akuntansi sudah mendengar berita tentang konverjensi IFRS tanpa ada tindakan lebih lanjut, 2 guru mendengar, mengetahui, dan dapat mencari tahu karena mendapat fasilitas dari Kementerian Pendidikan untuk belajar IFRS, sedangkan 2 lagi tidak mengetahui sama sekali. Ketika berdiskusi dengan salah satu guru yang sudah mendapatkan pelatihan IFRS diperoleh penjelasan bahwa kurikulum dari Dikti sifatnya kaku topiktopik pembelajarannya dianggap tidak terurut dengan rapi, boleh dikatakan secara langsung bagi guruguru akuntansi kurikulum dari Direktorat Pembinaan Sekolah Menengah Kejuruan kurang bagus dan menuai banyak kritikan. Secara internal kurikulum dari Direktorat Pembinaan Sekolah Menengah Kejuruan sendiri sudah memiliki konflik dan tidak up to date sejalan dengan kebutuhan. Kurikulum di salah satu SMK jurusan akuntansi dijelaskan dalam Tabel 1.

Tujuan pembelajaran normatif dan adaptif yaitu membentuk peserta diklat agar menjadi manusia yang berimandan bertaqwa, memiliki sikap bertanggung jawab dan berdisiplin, menguasai ilmupengetahuan, teknologi dan dasar-dasar keahlian sebagai bekal pengembangan dirinya,memiliki kesehatan jasmani dan rohani yang prima, memiliki watak dan kepribadiansebagai warga masyarakat dan bangsa Indonesia, mampu berkomunikasi dengan baik dan benar. Sementara, tujuan pembelajaran produktif bertujuan untuk membekali peserta dengan kompetisi yang sepadan dengan tuntutan duni kerjasekaligus menghasilkan produk/jasa yang laku dijual dan menanamkan pengalamanproduktif dan mengembangkan sikap wirausaha melalui pengalaman langsung memproduksi barang atau jasa yang berorientasi pasar (konsumen).

Tabel 1 Struktur Kurikulum Akuntansi

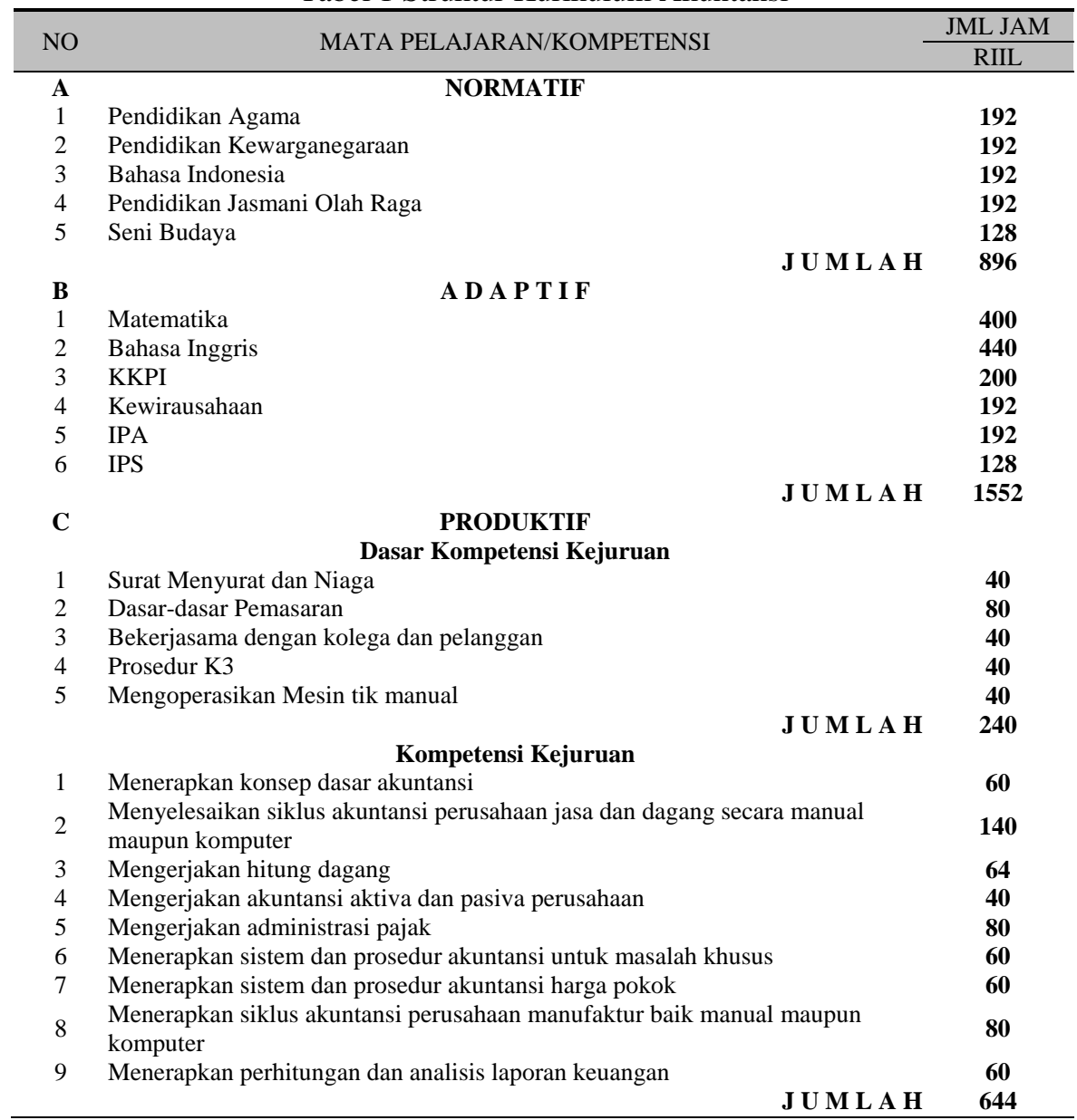


Untuk mengetahui permasalahan riil yang dihadapi oleh para pengajar/guru maka pada tanggal 7 Mei 2011 dilakukan survey yang melibatkan 11 guru dari 5 SMK Swasta dan Negeri. Tema acara tersebut adalah Sosialisasi IFRS bagi guru-guru Akuntansi SMK yang bertempat di Kampus Anggrek Universitas Bina Nusantara. Data-data hasil survei dapat dilihat pada Tabel 2 di bawah ini.

Tabel 2 Rekapitulasi Hasil Survei Pendahuluan

\begin{tabular}{|c|c|c|}
\hline \multicolumn{2}{|c|}{ Gambaran Responden } & 11 orang \\
\hline & Nama Sekolah & 5 sekolah \\
\hline & \multicolumn{2}{|l|}{ Nama Responden } \\
\hline & \multicolumn{2}{|l|}{ Jenis Kelamin } \\
\hline & Laki - laki & 3 \\
\hline & Perempuan & 8 \\
\hline & \multicolumn{2}{|l|}{ Lama Bekerja } \\
\hline & $<1$ tahun & 0 \\
\hline & 1 - 5 tahun & 1 \\
\hline & $>5$ tahun & 10 \\
\hline & \multicolumn{2}{|l|}{ Pendidikan terakhir } \\
\hline & S1 & 10 \\
\hline & S2 & 1 \\
\hline & S3 & 0 \\
\hline \multirow{6}{*}{1} & Usia & Rata2: 42 tahun \\
\hline & $\begin{array}{l}\text { Diprediksi kurikulum akan mengalami perubahan untuk } \\
\text { masa konverjensi IFRS }\end{array}$ & \\
\hline & $20 \%$ & 0 \\
\hline & $30 \%$ & 5 \\
\hline & $40 \%$ & 4 \\
\hline & $>40 \%$ & 2 \\
\hline \multirow[t]{5}{*}{2} & $\begin{array}{l}\text { Diperlukan pelatihan guru agar mengerti dalam menerapkan } \\
\text { IFRS }\end{array}$ & \\
\hline & Sangat setuju & 7 \\
\hline & Setuju & 4 \\
\hline & Tidak setuju & 0 \\
\hline & Sangat tidak setuju & 0 \\
\hline \multirow[t]{5}{*}{3} & $\begin{array}{l}\text { Penerapan IFRS disesuaikan dengan kondisi lingkungan } \\
\text { sekolah? Khususnya kurikulum }\end{array}$ & \\
\hline & Sangat setuju & 4 \\
\hline & Setuju & 7 \\
\hline & Tidak setuju & 0 \\
\hline & Sangat tidak setuju & 0 \\
\hline \multirow[t]{6}{*}{4} & $\begin{array}{l}\text { Ada faktor bahasa yang mempengaruhi penerapan IFRS } \\
\text { dalam kampus }\end{array}$ & \\
\hline & Sangat setuju & 3 \\
\hline & Setuju & 8 \\
\hline & Tidak setuju & 0 \\
\hline & Sangat tidak setuju & 0 \\
\hline & Faktor lingkungan sosial berpengaruh terhadap penerapan & \\
\hline \multirow[t]{5}{*}{5} & IFRS & \\
\hline & Sangat setuju & 1 \\
\hline & Setuju & 8 \\
\hline & Tidak setuju & 2 \\
\hline & Sangat tidak setuju & 0 \\
\hline \multirow[t]{5}{*}{6} & $\begin{array}{l}\text { Membutuhkan pengembangan infrastruktur dan sumber } \\
\text { daya untuk mendukung IFRS dalam sekolah }\end{array}$ & \\
\hline & Sangat setuju & 5 \\
\hline & Setuju & 6 \\
\hline & Tidak setuju & 0 \\
\hline & Sangat tidak setuju & 0 \\
\hline \multirow[t]{5}{*}{7} & Penafsiran IFRS yang berbeda bisa menimbulkan perbedaan & \\
\hline & Sangat setuju & 3 \\
\hline & Setuju & 8 \\
\hline & Tidak setuju & 0 \\
\hline & Sangat tidak setuju & 0 \\
\hline
\end{tabular}


Tabel 2 Rekapitulasi Hasil Survei Pendahuluan (lanjutan)

\begin{tabular}{|c|c|c|}
\hline \multirow[t]{5}{*}{8} & $\begin{array}{l}\text { Konvergensi IFRS akan menimbulkan pembaharuan dalam } \\
\text { dunia akuntansi }\end{array}$ & \\
\hline & Sangat setuju & 2 \\
\hline & Setuju & 9 \\
\hline & Tidak setuju & 0 \\
\hline & Sangat tidak setuju & 0 \\
\hline \multirow[t]{5}{*}{9} & IFRS harus diadopsi seluruhnya sebagaimana adanya & \\
\hline & Sangat setuju & 0 \\
\hline & Setuju & 7 \\
\hline & Tidak setuju & 2 \\
\hline & Sangat tidak setuju & 2 \\
\hline \multirow[t]{5}{*}{10} & $\begin{array}{l}\text { Adopsi IFRS akan membutuhkan banyak pengeluaran } \\
\text { beban dalam sekolah }\end{array}$ & \\
\hline & Sangat setuju & 2 \\
\hline & Setuju & 6 \\
\hline & Tidak setuju & 3 \\
\hline & Sangat tidak setuju & 0 \\
\hline \multirow[t]{5}{*}{11} & $\begin{array}{l}\text { Adopsi IFRS akan membawa keuntungan di tingkat } \\
\text { internasional }\end{array}$ & \\
\hline & Sangat setuju & 4 \\
\hline & Setuju & 7 \\
\hline & Tidak setuju & 0 \\
\hline & Sangat tidak setuju & 0 \\
\hline \multirow[t]{5}{*}{12} & $\begin{array}{l}\text { IFRS dapat membantu Indonesia siap memasuki dunia } \\
\text { global }\end{array}$ & \\
\hline & Sangat setuju & 6 \\
\hline & Setuju & 5 \\
\hline & Tidak setuju & 0 \\
\hline & Sangat tidak setuju & 0 \\
\hline \multirow[t]{5}{*}{13} & $\begin{array}{l}\text { IFRS membuat laporan keuangan perusahaan akan lebih } \\
\text { mudah dipahami, dapat diperbandingkan dan menghasilkan } \\
\text { informasi yang valid untuk aktiva, hutang, ekuitas, } \\
\text { pendapatan dan beban perusahaan }\end{array}$ & \\
\hline & Sangat setuju & 4 \\
\hline & Setuju & 7 \\
\hline & Tidak setuju & 0 \\
\hline & Sangat tidak setuju & 0 \\
\hline
\end{tabular}

Responden berjumlah 11 orang dari 5 SMK negeri dan swasta terdiri dari 3 responden laki laki dan 8 responden perempuan. Dari tabel di atas dapat diketahui bahwa hampir seluruh responden memiliki pengalaman kerja lebih dari 5 tahun (10 orang) dan hanya 1 orang dengan pengalaman kerja 1-5 tahun, dengan rata - rata usia 42 tahun. Sepuluh orang berpendidikan S1 dan hanya 1 orang berpendidikan S2. Seluruh responden memprediksi akan terjadi perubahan dalam kurikulum sebagai akibat konverjensi dengan IFRS (Pertanyaan \#1), sebesar 30\% dipilih oleh 5 responden, $40 \%$ oleh 4 responden dan lebih dari $40 \%$ oleh 2 responden. Kesebelas responden memilih setuju dan sangat setuju bahwa diperlukan pelatihan IFRS bagi para guru (Pertanyaan \#2), perlu penyesuaian antara IFRS dan kurikulum sekolah (Pertanyaan \#3), serta terdapat faktor bahasa yang mempengaruhi penerapan IFRS di sekolah (Pertanyaan \#4).

Seluruh responden juga memilih setuju dan sangat setuju penafsiran IFRS yang berbeda bisa menyebabkan perbedaan (Pertanyaan \#7), konverjensi IFRS membawa pembaruan dalam akuntansi (Pertanyaan \#8), IFRS membantu Indonesia memasuki pasar global (Pertanyaan \#12), IFRS membuat laporan keuangan perusahaan lebih mudah dipahami dan dibandingkan (Pertanyaan \#13), dan adopsi IFRS menguntungkan di tingkat internasional (Pertanyaan \#11).

Meskipun semua menganggap perlu pengembangan infrastruktur dan sumber daya dalam penerapan IFRS di sekolah (Pertanyaan \#6, 5 memilih sangat setuju dan 6 setuju), pendapat responden terpecah dalam menentukan apakah adopsi IFRS akan banyak membebani pengeluaran sekolah 
(Pertanyaan \#10, 2 orang sangat setuju, 6 orang setuju, dan 3 orang tidak setuju). Pendapat beragam juga terlihat saat menentukan apakah faktor lingkungan sekolah berpengaruh terhadap penerapan IFRS (Pertanyaan \#5, 1 sangat setuju, 8 setuju, dan 2 tidak setuju), serta apakah IFRS harus diadopsi secara keseluruhan (Pertanyaan \#9, 7 setuju, 2 tidak setuju dan 2 sangat tidak setuju).

\section{PENUTUP}

Dari hasil survei kecil ini dapat disimpulkan permasalahan yang dihadapi guru pengajar Akuntansi tingkat SMU/SMK adalah: (1) kurikulum pendidikan Akuntansi yang ada saat ini serta buku ajarnya masih belum selaras dengan perubahan standar keuangan di Indonesia yang sekarang berbasis IFRS utamanya PSAK; (2) pengetahuan guru-guru pengajar Akuntansi mengenai perubahan standar masih sangat kurang sehingga diperlukan pelatihan serta buku teks bagi para guru dan buku ajar bagi para murid; dan (3) khususnya bagi murid-murid SMK dirasakan kesulitan dalam bersaing dengan lulusan dari SMU bila melanjutkan ke perguruan tinggi terutama dari sisi nalar berpikir sehingga diperlukan pendekatan baru dalam melakukan pengajaran apalagi IFRS menganut principle based yang memerlukan kemampuan menerapkan professional judgement yang baik.

Saran yang diberikan adalah diadakannya sosialisasi informasi tentang IFRS di sekolahsekolah, pelatihan IFRS khusus guru-guru SMK, penyusunan modul-modul akuntansi yang sudah dikombinasikan dengan IFRS agar dapat digunakan di SMK dan penambahan mata pelajaran IFRS adalah sangat dianjurkan. Tapi hal yang paling utama adalah adanya kerja sama perbaikan kurikulum antara Direktorat Pembinaan Sekolah Menengah Kejuruan dengan tenaga pengajar terkait.

\section{DAFTAR PUSTAKA}

IAI.com (2010). Standar Internasional Dipakai 2012. Diakses tanggal 4 Januari 2011 http://www.iaiglobal.or.id/berita/detail.php?catid=\&id=138

Nasution, S. (2008). Kurikulum dan Pengajaran, Bumi Aksara

Shvoong.com (2012). Pengertian kurikulum Menurut Para Ahli. Diakses tanggal 1 Februari 2012. http://id.shvoong.com/social-sciences/education/2251368-pengertian-kurikulum-menurutpara-ahli/\#ixzz1l4Kz4uYN 